\title{
GAMBARAN STATUS MENTAL PADA PASIEN SKIZOFRENIA DI LEMBAGA KESEJAHTERAAN SOSIAL YAYASAN AL FAJAR BERSERI BEKASI
}

\author{
Nuram Mubina \\ Kristi Candra Rafika Devi \\ nuram.mubina@ubpkarawang.ac.id
}

Fakultas Psikologi Universitas Buana Perjuangan Karawang

\begin{abstract}
Schizophrenia is a mental disorder that shows disruption in cognitive function (mind) in the form of disorganization, Schizophrenia attacks at productive age and is the most dominant mental disorder compared to other mental disorders. An assessment of the mental status of schizophrenic patients is done to find out how emotional and psychomotor levels and behavior. Mental rehabilitation institutions are the main place for schizophrenics. This report contains the mental status of Schizophrenic patients at the Al Fajar Berseri Foundation. The subjects in this study consisted of two respondents. Data collection uses interview and observation techniques. The research method used is descriptive qualitative research. The conclusion of the study is the cause of schizophrenia, namely environmental factors such as stress due to stress caused by the environment, psychological such as inability to solve problems internally.
\end{abstract}

Keywords: Schizophrenia, mental status

Abstrak. Skizofrenia merupakan kelainan jiwa yang menunjukkan gangguan dalam fungsi kognitif (pikiran) berupa disorganisasi, skizofrenia menyerang pada usia produktif dan merupakan gangguan jiwa yang paling mendominasi dibandingkan gangguan jiwa lainnya. Pengkajian pada status mental pasien Skizofrenia dilakukan untuk mengetahui bagaimana tingkat dan perilaku emosi serta psikomotor. Panti rehabilitasi mental menjadi tempat yang utama untuk para penderita skizofrenia. Laporan ini berisi tentang status mental pasien Skizofrenia di Yayasan Al Fajar Berseri. Subjek dalam penelitian ini terdiri dari dua responden. Pengumpulan data menggunakan teknik wawancara dan Observasi. Metode penelitian yang digunakan yaitu penelitian kualitatif deskriptif. Kesimpulan penelitian adalah penyebab skizofrenia yaitu faktor lingkungan seperti stress akibat tekanan yang disebabkan oleh lingkungan, psikologis seperti ketidakmampuan dalam pemecahan masalah secara internal.

Kata kunci: Skizofrenia, status mental 


\section{Pengantar}

Panti disabilitas mental merupakan lembaga kesejahteraan sosial untuk para penyandang disabilitas mental. Penyandang disabilitas mental adalah orang dengan gangguan jiwa (ODMK) yang dalam jangka waktu lama mengalami hambatan dalam interaksi dan partisipasi di masyarakat berdasarkan kesetaraan dengan yang lainnya. ODMK adalah orang yang mempunyai masalah fisik, mental, sosial, pertumbuhan dan perkembangan, dan/atau kualitas hidup sehingga memiliki risiko mengalami gangguan jiwa. Orang dengan gangguan jiwa (ODGJ) adalah orang yang mengalami gangguan dalam pikiran, perilaku, dan perasaan yang termanifestasi dalam bentuk sekumpulan gejala dan/atau perubahan perilaku yang bermakna, serta dapat menimbulkan penderitaan dan hambatan dalam menjalankan fungsi orang sebagai manusia.

Permasalahan gangguan jiwa menurut Undang-Undang Kesehatan Jiwa No. 18 Tahun 2014 merupakan permasalahan yang berkaitan dengan gangguan dalam pikiran, perilaku, dan perasaan yang termanifestasi dalam bentuk sekumpulan gejala dan/atau perubahan perilaku. Permasalahan gangguan jiwa dapat dialami oleh siapa saja, dan dapat menimbulkan beban tidak saja bagi penyandangnya tetapi juga bagi keluarganya, apabila tidak mendapatkan penanganan secara tepat.

Sebagai salah satu Lembaga yang bergerak di bidang sosial, Yayasan Al Fajar Berseri bertujuan untuk mendukung bidang pembangunan bidang kesejahteraan sosial yang penting sesuai dengan Undang-Undang Nomor 11 Tahun 2009 tentang Kesejahteraan Sosial dan merupakan bagian dari salah satu tugas pokok Dinas Sosial adalah memberikan pelayanan dalam rangka rehabilitisasi sosial dan juga perlindungan sosial terhadap para Penyandang Masalah Kesejahteraan Sosial (PMKS).

Pada era globalisasi ini keadaan dunia termasuk kesehatan telah berkembang dengan sangat pesat, yang ditandai dengan perkembangan di berbagai bidang dalam segi kehidupan. Keadaan ini tentu saja berdampak terjadinya globalisasi di berbagai bidang, sehingga terjadi pergeseran sosial budaya, perilaku, norma, dan gaya hidup masyarakat. Semakin tinggi peradaban manusia, maka kebutuhan terhadap keinginan manusia juga semakin tinggi. Manusia bekerja tanpa mengenal lelah seperti mesin yang ditunggu waktu, kondisi ini dapat mengakibatkan stres yang tinggi pada manusia. Perubahanperubahan yang terjadi dengan disadari atau tanpa disadari dapat memberikan pengaruh yang sangat besar terhadap terjadinya transisi epidemiologi, hal ini ditandai dengan perubahan keadaan penyakit dari jenis infeksi yang menular ke arah kasus-kasus penyakit tidak menular dan gangguan jiwa. Penyakit gangguan jiwa tidak bisa hanya dipandang sebelah mata (Fusfita, 2017). Gangguan jiwa terjadi tidak hanya pada kalangan menengah kebawah sebagai dampak dari perubahan sosial ekonomi, tetapi juga kalangan menengah keatas yang 
disebabkan karena tidak mampu mengelola stress (Fusfita, 2017).

Dokter spesialis kejiwaan dari Direktorat Bina Kesehatan Jiwa Direktorat Jendral Bina Upaya Kesehatan, dr. Edduwar, Sp.KJ, menyatakan penelitian jangka panjang menunjukkan penderita skizofrenia dapat hidup produktif. Penanganan yang menyeluruh dan efektif dapat memperbaiki kualitas hidup penderita skizofrenia. Penanganan yang dimaksud bukan hanya berupa obat-obatan, namun juga dukungan lingkungan sosial. Lingkungan dan keluarga yang menerima penderita dengan sikap yang empati akan membantu penderita kembali aktif dalam kegiatan produktif (Skizofrenia Bisa Disembuhkan, Pikiran Rakyat Online, 2011, 14 Oktober).

Kesehatan jiwa adalah kondisi jiwa seseorang yang terus tumbuh berkembang dan mempertahankan keselarasan dalam pengendalian diri, serta terbebas dari stres yang serius (Fusfita, 2017). Hasil survey dari world health organization (WHO, 2012) menyatakan bahwa sekitar 450 jiwa penduduk di seluruh dunia mengalami gangguan kesehatan jiwa, yang memiliki arti bahwa jumlah penduduk dunia $10 \%$ nya mengalami gangguan kesehatan jiwa, kenyataan ini dibuktikan dengan laporan dari hasil riset bank dunia dan hasil survei badan pusat statistik yang melaporkan bahwa penyakit yang merupakan akibat masalah kesehatan jiwa mencapai 8,1 \% yang merupakan angka tertinggi dibanding presentasi penyakit lain. Menurut data riset Kesehatan Dasar (Riskesdas) tahun 2013 Departemen Kesehatan Republik Indonesia (Depkes RI) menyatakan bahwa prevalensi gangguan jiwa adalah 1-2 orang per 1.000 populasi. Prevalensi gangguan jiwa berat pada penduduk Indonesia 1,7 per mil dan gangguan jiwa terbanyak adalah Skizofrenia. Jawa tengah merupakan salah satu propinsi yang menempati urutan ke lima terbanyak penderita Skizofrenia. Prevalensi Skizofrenia di Jawa Tengah yaitu $0.23 \%$ dari jumlah penduduk melebihi angka nasional $0.17 \%$ (Riskesdas, 2013).

Skizofrenia sering terjadi pada masa remaja atau dewasa awal yang kebanyakan dialami oleh lakilaki sekitar usia 15-35 tahun dibandingkan dengan perempuan sekitar 25-35 tahun (Kokurcan et al., 2015).

Skizofrenia ditemukan 7 per 1000 orang dewasa dan menurut (Fusfita, 2017) Skizofrenia menyerang pada usia produktif 15-44 tahun dan merupakan gangguan jiwa yang paling mendominasi dibandingkan gangguan jiwa lainnya. Lama menderita skizofrenia biasanya antara rentang 10-20 tahun.

Skizofrenia adalah suatu gangguan psikiatrik yang memiliki tanda dan gejala disorganisasi pola pikir, masalah pada komunikasi dan kognisi, dan gangguan persepsi terutama halusinasi dan waham. Menurut (Fusfita, 2017) gejala-gejala lain dari Skizofrenia antara lain mengabaikan penampilan pada dirinya, cenderung menarik diri dari lingkungan sosial, pembicaraan yang kacau dan sukar dimengerti, inkoheren, gejala katatonik, stupor, gelisah, negativisme, gangguan afek, halusinasi dan waham.

Skizofrenia merupakan gangguan mental yang sangat berat. 
Gangguan ini ditandai dengan gejalagejala positif seperti pembicaraan yang kacau, delusi, halusinasi, gangguan kognitif, dan persepsi, dan gejala-gejala lainnya. Gejala skizofrenia ini akan menyebabkan pasien skizofrenia mengalami penurunan fungsi ataupun ketidakmampuan dalam menjalani hidupnya, sangat terhambat produktivitasnya dan nyaris terputus relasinya dengan orang lain (Arif, 2006).

Prevelensi penderita skizofrenia di Indonesia adalah 0.3-1 persen dan biasanya timbul pada usia sekitar 18 - 45 tahun, namun ada juga yang berusia lebih dini. Skizofrenia adalah gangguan mental yang cukup luas dialami di Indonesia, dimana sekitar 99\% pasien rumah sakit jiwa di Indonesia adalah penderita Skizofrenia. Skizofrenia ini tidak hanya menimbulkan penderitaan bagi penderitanya, tetapi juga bagi orangorang terdekatnya. Biasanya keluargalah yang terkena dampak hadirnya Skizofrenia di keluarga mereka. Sehingga pengetahuan tentang skizofrenia dan pengenalan tentang gejala-gejala munculnya skiofrenia oleh keluarga dan lingkungan sosialnya akan sangat membantu dalam pemberian penanganan pasien penderita skizofrenia lebih dini sehingga akan mencegah berkembangnya gangguan mental yang sangat berat ini (Arif, 2006).

\section{Skizofrenia}

Menurut Davidson (2012) Skizofrenia adalah gangguan psikotik yang ditandai dengan gangguan utama dalam pikiran emosi, dan perilaku-pikiran yang terganggu, dimana berbagai pemikiran tidak saling berhubungan secara logis; persepsi dan perhatian yang keliru; afek datar atau tidak sesuai; dan berbagai gangguan aktivitas bizarre. Bleuler (dalam Permatasari, 2016) mendefinisikan istilah skizofrenia yaitu yang menunjukkan pemisahan antara pikiran, emosi dan perilaku orang yang mengalaminya.

Terdapat tiga simptom klinis skizofrenia yaitu simptom positif, simptom negative, dan simptom disorganisasi (Davidson, 2012). Simtom-simtom positif mencakup hal-hal yang berlebihan dan distorsi, seperti halusinasi dan waham. Simtom-simtom ini, sebagian terebesarnya, menjadi ciri suatu episode akut skizofrenia (Davidson dkk, 2014). Waham (delusi), yaitu keyakinan yang berlawanan dengan kenyataan, semacam itu merupakan simtom-simtom positif yang umum pada skizofrenia. Menurut Davidson (2012) grandeur (waham kebesaran) Pasien yakin bahwa mereka adalah seseorang yang sangat luar biasa, misalnya seorang artis terkenal, atau seorang nabi atau merasa diri sebagai Tuhan. Halusinasi adalah persepsi sensorik yang salah dimana tidak terdapat stimulus sensorik yang berkaitan dengannya.

Simtom-simtom negative skizofrenia mencakup berbagai deficit behavioral, seperti avolition, alogia, anhedonia, afek datar, dan asosialitas. Avolition (apati) Merupakan kondisi kurangnya energi dan ketiadaan minat atau ketidakmampuan untuk tekun melakukan apa yang biasanya merupakan aktivitas rutin. Alogia Merupakan suatu gangguan pikiran negatif, alogia dapat terwujud dalam 
beberapa bentuk. Anhedonia Ketidakmampuan untuk merasakan kesenangan yang tercermin dalam kurangnya minat dalam berbagai aktivitas rekreasional, gagal untuk mengembangkan hubungan dekat dengan orang lain, kurangnya minat dalam hubungan seks. Asosialitas Ketidakmampuan yang parah dalam hubungan sosial, mereka hanya memiliki sedikit teman, keterampilan sosial yang rendah, dan sangat kurang berminat untuk berkumpul bersama orang lain.

$\begin{array}{cc}\text { Simptom } & \text { Disorganisasi } \\ \text { Disorganisasi } & \text { Pembicaraan }\end{array}$

(Gangguan Berpikir Formal) Menurut (Davidson dkk, 2014) merujuk pada masalah dalam mengorganisasi berbagai pemikiran dan dalam berbicara sehingga pendengar dapat memahaminya. Perilaku Aneh (Bizzare) Menurut (Davidson dkk, 2014) perilaku aneh terwujud dalam banyak bentuk. ODS dapat meledak dalam kemarahan atau konfrontasi singkat yang tidak dapat dimengerti, memakai pakaian yang tidak biasa, bertingkah laku seperti anak-anak atau gaya yang konyol, menyimpan makanan, mengumpulkan sampah, atau melakukan aktivitas seksual yang tidak pantas seperti masturbasi di tempat umum.

Simptom Lain Menurut (Davidson dkk, 2014) beberapa simptom lain skizofrenia tidak cukup tepat untuk digolongkan ke dalam ketiga kategori sebelumnya. Dua simptom penting dalam kelompok ini adalah katatonia dan afek tidak sesuai. Katatonia beberapa abnormalitas motorik menjadi ciri katatonia. Para ODS dapat melakukan suatu gerakan berulang kali, menggunakan urutan yang aneh dan kadang kompleks antara gerakan jari, tangan, dan lengan, yang sering kali tampaknya mempunyai tujuan tertentu. Afek yang Tidak Sesuai respon-respon emosional yang ditampilkan sering tidak sesuai dengan konteks misalnya paseie dapat tertawa ketika mendengar bahwa ibunya baru saja meninggal atau marah ketika ditanya dengan pertanyaan sederhana

\section{Metode}

Model penelitian yang digunakan dalam penelitian ini adalah metode studi kasus, karena peneliti ingin melakukan proses analisis secara mendalam terhadap dua obyek penelitian yang unit analisisnya bersifat individual (Hanurawan, 2012). Pengumpulan data dilakukan dengan metode observasi dan wawancara. Subjek dalam penelitian ini merupakan dua responden yang memiliki karakteristik yang berusia 30 dan 38 tahun atau berada pada masa dewasa. Analisis data dilakukan dengan reduksi data, penyajian data dan penarikan kesimpulan. Penyajian data dalam penelitian ini dalam bentuk uraian kata yang bersifat naratif.

\section{Hasil}

Berdasarkan Hasil Observasi dan Wawancara dengan pengasuh pasien.

Data subjek 1

\begin{tabular}{|c|c|}
\hline Nama & $\mathrm{AB}$ \\
\hline Jenis Kelamin & Laki-laki \\
\hline Usia & 38 Tahun \\
\hline
\end{tabular}

penulis akan memaparkan tentang keadaan subjek. AB berasal dari kota 
Bogor dengan pendidikan terakhir SMK. Status AB yaitu belum menikah. AB sudah 1 tahun berada di yayasan. Hal yang melatar belakangi mengapa $\mathrm{AB}$ dirawat di yayasan karena faktor ekonomi. AB di PHK oleh perusahaan lamanya sehingga AB tidak bekerja dan tidak ada penghasilan, sedangkan $\mathrm{AB}$ ada tuntutan dari keluarga untuk membiayai kebutuhan hidup keluarga. Dalam segi penampilan A.B terlihat berantakan dan kumal, gigi terlihat kuning serta kotor dan mempunyai aroma tertentu. Dalam keseharian $\mathrm{AB}$ tidak meminum obat obatan yang diberikan oleh dan tidak adanya pendampingan secara psikologis, hal ini berpengaruh terhadap tingkah laku $A B$ sehingga $\mathrm{AB}$ cenderung banyak bicara. $\mathrm{AB}$ sering kali bersikap curiga bahwa temannya mengambil pakaian milik $\mathrm{AB}$ dan sering memukul temannya jika temannya meninggalkan $\mathrm{AB}$ ketika sedang berbicara. Kegiatan sehari - hari yang dilakukan AB yaitu mengepel aula.

\section{Gambaran Status Mental AB}

A. Simptom Positif

1. Delusi

(Waham Kebesaran) AB menyebutkan bahwa dirinya adalah seorang jegger (preman) yang berasal dari kota Bogor, dan AB mengatakan bahwa dirinya adalah seorang malaikat.

2. Halusinasi

(Halusinasi Auditory) AB sering berbicara sendiri tentang ponakannya, menurut $\mathrm{AB}$ ponakannyalah yang sudah menghasut ayah $\mathrm{AB}$ untuk membawa $\mathrm{AB}$ ke yayasan.

B. Simptom Negatif

1. Avolition (Apati)

$A B$ tidak mau mengganti pakaiannya ketika pengasuh $\mathrm{AB}$ menyuruh $\mathrm{AB}$ untuk mandi.

2. Asosialitas

Ketika AB sedang ngobrol dengan salah satu temannya yang $A B$ tidak sukai $A B$ mengatakan bahwa temannya tidak sepaham atau beranggapan bahwa temannya adalah seorang dajal dan musuhnya oleh sebab itu $A B$ suka menyendiri.

C. Simptom Lain

1. Katakonia

$\mathrm{AB}$ sering menggerakatan tangannya berulang kali dan $\mathrm{AB}$ sering melakukan tinju karena $\mathrm{AB}$ merasa seolaholah dirinya adalah seorang petinju.

2. Afek yang tidak sesuai

Karena keinginan $\mathrm{AB}$ yang ingin menjadi arsitek dan membuat jembatan dikampungnya. Ketika pengasuh $\mathrm{AB}$ menyuruh $\mathrm{AB}$ untuk mengganti pakaiannya yang sudah bau karena sudah dua hari tidak ganti, dan $\mathrm{AB}$ selalu beranggapan bahwa pakaian yang $\mathrm{AB}$ pakai masih baru.

Data subjek 2

\begin{tabular}{ll}
\hline Nama & A \\
\hline Jenis Kelamin & Laki-laki \\
\hline Usia & 30 Tahun \\
\hline
\end{tabular}


Berdasarkan data di atas, penulis akan memaparkan tentang keadaan subjek. A berasal dari provinsi Jambi dengan pendidikan terakhir S1 jurusan teknik mesin. Status A yaitu belum menikah. A sudah 3 tahun tinggal diyayasan. Hal yang melatar belakangi mengapa $\mathrm{A}$ dirawat di yayasan karena usahanya gulung tikar sehingga menyebabkan A depresi, karena faktor depresi itulah A harus dirawat di Yayasan. Dalam segi penampilan, A terlihat rapi, gigi terlihat kotor dan mempunyai aroma tertentu walaupun rajin mandi dan mengganti pakaiannya. Dalam berbicara A cenderung terlalu banyak bicara dan jika berbicara sambil tertawa. Dalam keseharian A tidak meminum obat - obatan yang diberikan oleh dan tidak adanya pendampingan secara psikologis, hal ini berpengaruh terhadap tingkah laku A yaitu suka jalan - jalan sambil berbicara tentang keluarganya dan memukul - mukul tubuhnya.

\section{Gambaran Status Mental A}

A. Simptom Positif

1. Halusinasi

(Halusinasi Auditory) A sering jalan-jalan sambil berbicara tentang keluarganya dan yang paling sering disebut oleh A adalah tentang ibunya.

B. Simptom Negatif

1. Avolition (Apati )

A sangat tidak suka melakukan kegiatan apa yang diperintahkan oleh pengasuhnya seperti membuang sampah dan membersihkan makanannya.

2. Alogia
A sering kali mengulang ulang perkataannya ketika sedang ditanya tentang masalah pemilu.

\section{Anhedonia}

$A$ adalah teman baik $A B$ hal ini disebabkan A selalu berbagi makanan dengan $A B$ dan $A B$ juga cenderung berperilaku seperti itu.

4. Asosialitas

$A$ adalah teman baik $A B$ hal ini disebabkan A selalu berbagi makanan dengan $\mathrm{AB}$ dan $\mathrm{AB}$ juga cenderung berperilaku seperti itu.

C. Simptom Disorganisasi

1. Pembicaraan (Gangguan berpikir formal )

Ketika sedang mengaji, ustad bertanya pada A tentang politik dan A menjawab hanya seperkian detik nyambung lalu A tiba-tiba menyebutkan macam-macam penyakit seksual seperti sifilis dan raja singa.

D. Simptom Lain

1. Afek yang tidak sesuai A selalu marah dengan sendirinya yang tidak beraturan. Marah A selalu tentang politik, dan keluarganya. Ketika membaca puisi A selalu tertawa untuk menghilangkan rasa malu dan pada saat membaca puisi A sangat dalam mengekspresikannya seolah-olah A paham tentang puisi yang dibuatnya.

\section{Diskusi}

Menurut Davison (2012) Skizofrenia adalah gangguan psikotik yang ditandai dengan gangguan utama dalam pikiran emosi, dan perilaku-pikiran yang terganggu, dimana berbagai pemikiran tidak saling berhubungan secara logis; 
persepsi dan perhatian yang keliru; afek datar atau tidak sesuai; dan berbagai gangguan aktivitas bizarre. Pasien menarik diri dari banyak orang dan realitas, seringkali kedalam kehidupan fantasi yang penuh waham dan halusinasi. Berdasarkan hasil wawancara dengan pengasuh dan observasi pada pasien yang dilakukan pada dua pasien skizofrenia di panti disabilitas mental yayasan al Fajar Berseri Tambun, Bekasi. Peneliti menemukan bahwa subjek tersebut memiliki gambaran status mental skizoifrenia, karena adanya tiga simptom klinis skizofrenia yaitu simptom positif, simptom negative, dan simptom disorganisasi hal ini dibuktikan dengan wawancara mendalam terhadap pengasuh dan observasi pada pasien.

Simtom-simtom positif mencakup hal-hal yang berlebihan dan distorsi seperti halusinasi dan waham. Simtom-simtom ini, sebagian terebesarnya, menjadi ciri suatu episode akut skizofrenia (Davidson dkk, 2014). Waham (delusi), yaitu keyakinan yang berlawanan dengan kenyataan, semacam itu merupakan simtom-simtom positif yang umum pada skizofrenia. Menurut Davidson (2012) grandeur (waham kebesaran) pasien yakin bahwa mereka adalah seseorang yang sangat luar biasa, misalnya seorang artis terkenal, atau seorang nabi atau merasa diri sebagai Tuhan. Halusinasi adalah persepsi sensorik yang salah dimana tidak terdapat stimulus sensorik yang berkaitan dengannya. Halusinasi dapat berwujud penginderaan kelima indera yang keliru, tetapi yang paling sering adalah halusinasi dengar (auditory) dan halusinasi penglihatan (visual). Pada kenyataannya tidak ada. Yang paling sering terjadi adalah halusinasi auditori, bukan visual, 74 $\%$ dari suatu sampel menuturkan mengalami halusinasi auditori menurut Sartorius dkk (dalam Davidson dkk, 2014).

Simtom-simtom negative skizofrenia mencakup berbagai deficit behavioral, seperti avolition, alogia, anhedonia, afek datar, dan asosialitas. Simtom-simtom ini cenderung bertahan melampaui satu episode akut dan memiliki efek parah terhadap kehidupan para pasien skozofrenia. Simtom-simtom ini juga penting secara prognostic; banyaknya simtom negative merupakan predictor kuat terhadap kualitas hidup yang rendah (ketidak mampuan kerja, hanya memiliki sedikit teman) dua tahun setelah dirawat rumah sakit (Ho dkk., 1998 dalam Davison, 2006). Avolition (apati) merupakan kondisi kurangnya energi dan ketiadaan minat atau ketidakmampuan untuk tekun melakukan apa yang biasanya merupakan aktivitas rutin. Misalnya menjaga kebersihan diri dan mengalami kesulitan untuk tekun dalam beraktivitas seperti sekolah, bekerja, dan pekerjaan rumah tangga. Alogia Merupakan suatu gangguan pikiran negatif, alogia dapat terwujud dalam beberapa bentuk. Misalnya miskin percakapan, jumlah percakapan memadai namun hanya mengandung sedikit informasi dan cendrung membingungkan serta diulang-ulang. Anhedonia, ketidakmampuan untuk merasakan kesenangan yang tercermin dalam kurangnya minat dalam berbagai aktivitas rekreasional, gagal untuk mengembangkan hubungan dekat dengan orang lain, kurangnya minat dalam hubungan seks. Asosialitas 
Ketidakmampuan yang parah dalam hubungan sosial, mereka hanya memiliki sedikit teman, keterampilan sosial yang rendah, dan sangat kurang berminat untuk berkumpul bersama orang lain.

Simptom disorganisasi disorganisasi pembicaraan (Gangguan berpikir formal). Menurut (Davidson dkk, 2014) merujuk pada masalah dalam mengorganisasi berbagai pemikiran dan dalam berbicara sehingga pendengar dapat memahaminya. Perilaku aneh (bizzare) menurut (Davidson $\mathrm{dkk}$, 2014) perilaku aneh terwujud dalam banyak bentuk. ODS dapat meledak dalam kemarahan atau konfrontasi singkat yang tidak dapat dimengerti, memakai pakaian yang tidak biasa, bertingkah laku seperti anak-anak atau gaya yang konyol, menyimpan makanan, mengumpulkan sampah, atau melakukan aktivitas seksual yang tidak pantas seperti masturbasi di tempat umum.

Simptom Lain Menurut (Davidson dkk, 2014) beberapa simptom lain skizofrenia tidak cukup tepat untuk digolongkan ke dalam ketiga kategori sebelumnya. Dua simptom penting dalam kelompok ini adalah katatonia dan afek tidak sesuai. Katatonia beberapa abnormalitas motorik menjadi ciri katatonia. Para ODS dapat melakukan suatu gerakan berulang kali, menggunakan urutan yang aneh dan kadang kompleks antara gerakan jari, tangan, dan lengan, yang sering kali tampaknya mempunyai tujuan tertentu. Beberapa ODS menunjukkan peningkatan yang tidak biasa pada keseluruhan kadar aktivitas, termasuk sangat riang, menggerakkan anggota badan secara liar, dan pengeluaran energi yang sangat besar seperti yang terjadi dalam mania. Di ujung lain spektrum ini adalah imobilitas katatonik: ODS menunjukkan postur yang tidak biasa dan tetap dalam posisi demikian untuk waktu yang sangat lama. Afek yang Tidak Sesuai respon-respon emosional yang ditampilkan sering tidak sesuai dengan konteks misalnya paseie dapat tertawa ketika mendengar bahwa ibunya baru saja meninggal atau marah ketika ditanya dengan pertanyaan sederhana, misalnya apakah baju barunya cocok untuknya. Para ODS tersebut dapat dengan cepat berubah dari satu kondisi emosional ke kondisi emosional yang lain tanpa alasan yang jelas.

\section{Kesimpulan}

Berdasarkan hasil penelitian dapat disimpulkan bahwa gambaran status mental pada pasien skizofrenia di panti disabilitas mental Yayasan $\mathrm{Al}$ Fajar Berseri tergolong dalam tiga simptom klinis skizofrenia yaitu simptom positif, simptom negatif,dan simptom disorganisasi hal ini terjadi karena para pasien tidak meminum obat - obatan serta pendampingan secara psikologis. Terdapat faktor penyebab skizofrenia yaitu faktor lingkungan seperti stress akibat tekanan yang disebabkan oleh lingkungan, psikologis seperti ketidakmampuan dalam pemecahan masalah secara internal. 


\section{Kepustakaan}

Arif, I. S. (2006). Skizofrenia memahami dinamika keluarga pasien. Bandung: Refika Aditama.

Davison, C., \& Neale, J., Kring, A. (2010). Psikologi Abnormal. Ed. Ke-9. Jakarta: Raja Grafindo Persada.

Fatmawati, I. (2016). Faktor-faktor penyebab skizofrenia di rumah sakit jiwa di Surakarta. Skripsi. Surakarta: Universitas Muhammadiyah Surakarta.

Fusfita, Y. (2017). Gambaran status mental pasien skizofrenia di rumah sakit jiwa Soedjarwa di Klaten. Skripsi. Surakarta: Universitas Muhammadiyah Surakarta.
Hanurawan, F. 2012. Metode penelitian kualitatif dalam ilmu psikologi. Malang: Universitas Negeri Malang.

Permatasari, V., Gamayanti, W. (2016). Gambaran penerimaan diri (selfacceptance) pada orang yang mengalami skizofrenia. Jurnal Ilmiah Psikologi, 3(1), 139-152.

Riskesdas. (2013). Laporan nasional 2013. Retrieved from http://www.depkes.go.id

Skizofrenia Bisa Disembuhkan (2011, 14 Oktober). Pikiran Rakyat [on-line]. Diakses pada tanggal 23 Oktober 2011 dari http://www.pikiranrakyat.com/node/161922.

WHO. (2012). The world health report: 2012 : mental health : new understanding, new hope. Retrieved from www.who.int/whr/2012/en/ 